\section{The Linda Hall Library} of Science, Engineering, and Technology has received a gift of $\$ 500,000$ from Mrs. C. Humbert Tinsman Sr. and the late Mr. Tinsman. The gift, $\$ 50,000$ annually for ten years, is for the purchase of rare books for the library's already widely recognized special collection of rare books in the history of science and technology. The Linda Hall Library is the largest privately funded library of science, engineering, and technology in North America.

\section{The University of Illinois Library's} Mortenson Center for International Library Programs has received a $\$ 36,270$ grant from the Soros Foundation/Open Society Institute's Regional Library Program to help create a countrywide library and literacy program for Haiti. The one-year project will bring four Haitians to the university library to increase their knowledge of librarianship and literacy programs so that they can develop training workshops for their colleagues in Haiti.

\section{Clinch Valley College Library has re-} ceived a $\$ 500,000$ gift from the Slemp Foundation to purchase compact shelving for the addition to the John Cook Wyllie Library and to equip and furnish a new Special Collections and Archives Room. The gift will also enable the library to index existing collections and acquire new materials to enhance the special collections/archives. The slemp Foundation is named for C. Bascom Slemp, a member of the House of Representatives, and later, private secretary to President Calvin Coolidge.

\section{The Hill Monastic Manuscript Library} of Saint John's University has been awarded a $\$ 213,000$ grant from the Getty Grant Program to complete the entry of the library's Latin incipit card file into an electronic database for publication on $\mathrm{CD}-\mathrm{ROM}$. The resulting database will be a valuable reference tool for manuscript scholars and art historians throughout the world. Incipits, the first words of a text, are the surest and easiest way to identify a medieval manu- script and have long been an important tool for medieval scholars and art historians.

\section{The Golda Meir Library}

of the University of Wisconsin-Milwaukee has been awarded a $\$ 15,000$ grant from the Helen Bader Foundation, Inc., for the preservation and cataloging of a collection of rare pamphlets that document European Jewish history. The pamphlets were published in European Jewish communities from the 1800 s through the 1930 s and document all aspects of Judaism, Jewish culture, and Jewish scholarship in Germany and eastern Europe. Few copies were printed, and even fewer copies survived Nazi Germany. After the preservation work, the bibliographic records for the pamphlets will be added to the library's online catalog.

\section{University of California at Irvine Univer-} sity Advancement received $\$ 100,000$ from Carl A. Kroch (Kroch and Brentano's bookstore chain) to fund a charitable gift annuity that will ultimately endow the UIC Libraries' exhibits program. This is among the largest gifts ever given to the UCI Libraries. The earnings from the invested endowment will be used primarily for labor, materials, publications, and other costs of mounting professional-quality exhibits in the Mursel Ansley Reynolds Exhibit Gallery of the Main Library.

\section{The Huntington Library has received a} grant from the Andrew W. Mellow Foundation. Part of the $\$ 570,000$ grant will allow the library to complete a $\$ 1.2$ million retrospective conversion project with RetroLink, Inc., which will bring online the library's main rare book and research holdings, as well as the curatorial libraries of the Art and Botanical Divisions. Once the catalog is linked to the Huntington's homepage (www. huntington.org) later in 1998, re-

Ed. note: Send your news to: Grants E Acquisitions, C\&RL News, 50 E. Huron St., Chicago, IL 60611; e-mail: ayoung@ala.org 
searchers and scholars will have full bibliographic access from any location with Internet access.

\section{Acquisitions}

\section{Two William Faulkner television scripts}

have been found at Iuke University's Special Collection's Library, just in time for the centennial of the Nobel Prize-winning author's birth on September 25. The microfilm copies of "The Brooch" and "Shall Not Perish," the only two known scripts adapted by Faulkner from his own short stories and subsequently telecast, were found last November. Literary scholars previously thought the scripts were lost or destroyed. Sample pages of the scripts can be found on the Web at http. scriptorium.lib.duke.edu/hartman/jwt/ lux.html.

\section{The Treasury of Chinese Classics, one} of the most significant publications in Chinese history, was presented to the New York Public Library by the Chinese Association for Promotion of Culture Exchange and Cooperation, the United World Chinese Association, and Cheng Cheng Enterprises Holdings, Ltd. The 123 illustrated volumes, written in Chinese, cover a span of 5,000 years of history, philosophy, religion, arts, literature, medicine, war, science, and technology. A limited edition of 10,000 copies, the Treasury of Chinese Classics represents the efforts of more than 3,700 scholars and experts in Chinese cultural circles.

\section{Several rare editions of The Friend, a} periodical edited by Samuel Taylor Coleridge, have been discovered in an acquisition by the University of Manitoba Libraries' Department of Archives and Special Collections. The collection was formerly owned by Barbara E. Rooke, a major Coleridge scholar. The editions include an extremely rare collection of the original 28 issues of The Friend, dated $1809 / 10$, an 1818 edition of essays in three volumes, an 1844 edition in three volumes edited three years after Coleridge's death from his annotated 1818 copy by his nephew, and an 1865 edition in one volume with pencil annotations.
The papers of Ahmed M. Kathrada, parliamentary counselor to South African president Nelson Mandela, have been acquired by Michigan State University Libraries' Special Collections Division. Kathrada is a veteran of the South African liberation struggle and was held as a political prisoner with Nelson Mandela. The collection consists of microform copies of Kathrada's prison correspondence, including hundreds of letters to and from family members and friends written from 1964 to 1989.

\section{The Augusta Baker Collection of Afri-} can-American Children's Literature and Folklore has been established in the Special Collections area of the Thomas Cooper Library of the University of South Carolina in Columbia. The collection, recently donated to the library by Baker, was assembled during the 40 years she spent as children's librarian at the New York Pullic Library and the decade she served as storyteller-in-residence at the university's College of Library and Information Science.

The Native American Women Playwrights Archive was dedicated at the Miami University Libraries in Oxford, Ohio, earlier this year. Created by Humanities Librarian William Wortman and a theater graduate student, the archive is intended to identify Native American women playwrights; collect, preserve, and publicize their work; and encourage performance and continued creativity. The creation of the archive was supported by an anonymous $\$ 20,000$ donation.

\section{Advertiser index}

$\begin{array}{ll}\text { ACRL } & 720 \\ \text { Ameritech Library Services } & \text { Cover } 2 \\ \text { Baker \& Taylor } & 681 \\ \text { Broclart } & 692 \\ \text { CHOICE } & 712 \\ \text { EBSCO } & \text { Cover } 3 \\ \text { EBSCO.doc } & 697 \\ \text { Engineering Info. Inc. } & 691 \\ \text { Library Corporation } & 708 \\ \text { Merck Publishing } & \text { Cover 4 } \\ \text { Minolta } & 714-715 \\ \text { OCLC } & 684,710 \\ \text { Sociological Abstracts } & 702\end{array}$

